\title{
13. EXTREME INCOMPATIBLE TRACE-ELEMENT DEPLETION OF DIOPSIDE IN RESIDUAL MANTLE FROM SOUTH OF THE KANE FRACTURE ZONE ${ }^{1}$
}

\author{
Kent Ross ${ }^{2}$ and Don Elthon ${ }^{2}$
}

\begin{abstract}
Mineral compositions of primary phases in serpentinized peridotites drilled during Leg 153 of the Ocean Drilling Program have been determined by electron probe and ion probe. These peridotites have major-element mineral compositions that are typical of other suites of abyssal peridotites. Incompatible trace-element compositions of diopside in these rocks are extremely depleted, reaching levels that approach those in the most depleted diopsides in abyssal peridotites previously studied (Bouvet Fracture Zone and Hess Deep). The extreme depletion of incompatible trace elements of diopside in peridotites at the Kane Fracture Zone area is notable because this site is distant from any hot-spot-related volcanic activity, and it has been suggested that such extreme depletions only result from plume-related, high-degree melting. The Leg 153 peridotites are quite uniform in composition, both within individual samples and for the suite as a whole. The mantle in this region was fractionally melted to the extent that it was in equilibrium with melts much more depleted than erupted mid-ocean ridge basalts (MORBs), as has been shown for other suites of abyssal peridotites.
\end{abstract}

\section{INTRODUCTION}

Samples for this study were taken from two holes drilled into serpentinite outcrops exposed along the western wall of the median valley of the Mid-Atlantic Ridge, approximately $30 \mathrm{~km}$ south of the Kane Fracture Zone. These holes (Holes 920B and 920D) penetrated to depths of 126 and 201 meters below seafloor (mbsf), respectively. Forty-eight $\mathrm{m}$ of core was recovered from Hole $920 \mathrm{~B}$ and about $95 \mathrm{~m}$ was recovered from Hole 920D. The dominant lithology at both holes was serpentinized harzburgite to lherzolite, with minor orthopyroxene-bearing dunite, pyroxenite, crosscutting gabbroic veins, and rare diabase dikes also recovered. This study focuses on the geochemistry and petrogenesis of peridotites sampled distally from crosscutting magmatic veins, such as pyroxenites and gabbroic dikes. Shipboard characterization of the mineralogy and modes of the peridotites suggests that they are predominantly harzburgite (Cannat, Karson, Miller, et al., 1995). Point-counting of several large thin sections of peridotite samples was used to "calibrate" visual estimates of peridotite modes. Clinopyroxene occurs as relatively coarse multigrain clusters and as occasional fine grains within or near large orthopyroxene grains. Chrome spinel is a ubiquitous accessory phase in these peridotites. Only rarely is plagioclase observed, in samples that were interpreted to have been influenced by melt percolation or impregnation. The area in the vicinity of the Kane Fracture Zone has been referred to as the MARK area (Mid-Atlantic Ridge near Kane), and this abbreviation is used to refer to this area in this report.

\section{ANALYTICAL METHODS}

Major- and minor-element mineral compositions have been determined by electron microprobe analysis. These data were collected on the JEOL JXA-8600 Superprobe at the University of Houston. Polished thin sections were prepared from 28 rock samples from Site 920. X-ray intensity data were reduced using an on-line NORAN

'Karson, J.A., Cannat, M., Miller, D.J., and Elthon, D. (Eds.), 1997. Proc. ODP, Sci. Results, 153: College Station, TX (Ocean Drilling Program).

${ }^{2}$ Department of Chemistry, and the Texas Center for Superconductivity, University of Houston, Houston TX 77204-5641, U.S.A. DKROSS@UH.EDU
$\mathrm{ZAF}$ routine. The instrument was operated using an accelerating voltage of $15 \mathrm{kV}$ and a beam current of $30 \mathrm{nA}$. Six to nine spots on several grains for each major constituent phase were analyzed; average analyses are presented in the microprobe data tables that follow. Pyroxene analyses were obtained using a defocused beam with a diameter of $25 \mu \mathrm{m}$, in order to attempt to determine magmatic (pre-exsolution) pyroxene compositions. Exsolution lamellae of low-Ca pyroxene in host diopsides and of high-Ca pyroxene in orthopyroxene are ubiquitous. Chrome spinel and olivine were analyzed using a $1-\mu \mathrm{m}$ spot diameter. Elements were calibrated using natural and synthetic mineral and glass standards. Counting times were generally set at $100 \mathrm{~s}$ for the peak, with 50 -s counting times on background positions on each side of the peak.

Rare-earth and trace-element compositions of clinopyroxene were obtained by secondary ion mass spectrometry at the Woods Hole Oceanographic Institution in N. Shimizu's laboratory. Round, 1 -in, thin-section mounts of peridotites were prepared for ion probe studies, so that clinopyroxene grains could be analyzed in situ to permit evaluation of trace-element zoning. Energy filtering suppressed molecular interferences (Shimizu and Hart, 1982). The ion beam used for analyses of rare-earth elements (REEs) and trace elements was approximately $20-25 \mu \mathrm{m}$ in diameter, and the pit from which material was sputtered was about $20-25 \mu \mathrm{m}$ deep. The sizes of exsolution lamellae are small ( $<1$ to $3 \mu \mathrm{m}$ in width) relative to that of the probed spot in both ion probe and electron probe techniques. The presence of exsolution lamellae in diopside could contribute to variability in secondary ion yields during individual analyses (sputtering lasts about $20 \mathrm{~min}$ for analyses of the elements $\mathrm{Zr}, \mathrm{Y}, \mathrm{V}, \mathrm{Sr}, \mathrm{Ti}$, and $\mathrm{Cr}$, and for about 30 min for REE analyses) but is unlikely to contribute to variability in averaged data presented for these elements based on measurements of spots on 3 to 5 grains in each sample.

\section{MAJOR-ELEMENT MINERAL COMPOSITIONS}

Mean olivine compositions in MARK peridotites vary between $\mathrm{Fo}_{90.3}$ and $\mathrm{Fo}_{91.0}$. Mean $\mathrm{NiO}$ in olivine ranges from 0.39 to $0.42 \mathrm{wt} \%$. Olivine data are presented in Table 1. Olivine compositions from Leg 153 are typical of those found in other abyssal peridotites. Clinopyroxene Mg\# ranges from 90.9 to 93.6 (data in Table 2). Mean alumi- 
Table 1. Olivine compositions in Site 920 peridotites.

\begin{tabular}{|c|c|c|c|c|c|c|c|c|c|c|}
\hline $\begin{array}{l}\text { Core, section, } \\
\text { interval }(\mathrm{cm})\end{array}$ & $\mathrm{n}$ & $\mathrm{SiO}_{2}$ & $\mathrm{FeO}$ & $\mathrm{MnO}$ & $\mathrm{MgO}$ & $\mathrm{NiO}$ & $\mathrm{CaO}$ & Total & Fo & I s.d. \\
\hline \multicolumn{11}{|l|}{ 153-920D- } \\
\hline $8 R-2,94-100$ & 8 & 41.07 & 9.25 & 0.14 & 49.35 & 0.42 & 0.03 & 100.26 & 90.47 & \pm 0.17 \\
\hline $8 R-3,13-18$ & 8 & 41.09 & 9.39 & 0.13 & 49.29 & 0.41 & 0.04 & 100.35 & 90.33 & \pm 0.05 \\
\hline $11 R-4,9-16$ & 8 & 41.02 & 9.36 & 0.14 & 49.72 & 0.41 & 0.04 & 100.69 & 90.45 & \pm 0.10 \\
\hline $12 R-4,6-12$ & 8 & 40.52 & 9.27 & 0.14 & 49.56 & 0.40 & 0.03 & 99.92 & 90.50 & \pm 0.16 \\
\hline $14 \mathrm{R}-3,99-106$ & 8 & 40.95 & 8.15 & 0.15 & 49.68 & 0.41 & 0.04 & 99.38 & 90.52 & \pm 0.06 \\
\hline $14 \mathrm{R}-4,134-138$ & 8 & 40.90 & 9.04 & 0.14 & 49.37 & 0.41 & 0.05 & 99.91 & 90.69 & \pm 0.25 \\
\hline $15 R-3,21-28$ & 8 & 41.21 & 9.22 & 0.14 & 49.54 & 0.42 & 0.04 & 100.57 & 90.57 & \pm 0.26 \\
\hline $15 R-4,9-16$ & 8 & 40.97 & 9.34 & 0.14 & 49.73 & 0.41 & 0.06 & 100.65 & 90.47 & \pm 0.19 \\
\hline $15 R-4,102-108$ & 8 & 40.45 & 9.37 & 0.14 & 49.62 & 0.42 & 0.05 & 100.05 & 90.42 & \pm 0.14 \\
\hline $15 R-4,102-108$ & 8 & 40.82 & 9.11 & 0.14 & 49.73 & 0.39 & 0.05 & 100.24 & 90.71 & \pm 0.13 \\
\hline $15 R-6,59-64$ & 8 & 41.14 & 9.16 & 0.13 & 49.16 & 0.41 & 0.05 & 100.05 & 90.54 & \pm 0.06 \\
\hline $16 \mathrm{R}-1,125-131$ & 8 & 40.92 & 9.03 & 0.14 & 49.70 & 0.42 & 0.03 & 100.24 & 90.75 & \pm 0.11 \\
\hline $16 \mathrm{R}-3,92-98$ & 8 & 40.84 & 8.73 & 0.13 & 49.69 & 0.41 & 0.05 & 99.85 & 91.03 & \pm 0.20 \\
\hline $16 \mathrm{R}-4,14-20$ & 8 & 41.14 & 9.11 & 0.14 & 49.44 & 0.41 & 0.04 & 100.28 & 90.63 & \pm 0.06 \\
\hline $17 R-4,47-56$ & 8 & 40.65 & 9.27 & 0.14 & 49.88 & 0.42 & 0.03 & 100.39 & 90.55 & \pm 0.11 \\
\hline $22 \mathrm{R}-2,77-83$ & 8 & 41.14 & 9.16 & 0.13 & 49.65 & 0.42 & 0.04 & 100.54 & 90.62 & \pm 0.16 \\
\hline $22 \mathrm{R}-3,48-52$ & 8 & 40.70 & 9.13 & 0.14 & 49.34 & 0.41 & 0.05 & 99.77 & 90.59 & \pm 0.09 \\
\hline $22 R-7,7-12$ & 8 & 41.04 & 9.23 & 0.14 & 49.79 & 0.41 & 0.05 & 100.66 & 90.58 & \pm 0.21 \\
\hline \multicolumn{11}{|l|}{ 153-920B- } \\
\hline 7R-1, 94-97 & 8 & 40.96 & 9.14 & 0.13 & 49.67 & 0.42 & 0.03 & 100.35 & 90.64 & \pm 0.09 \\
\hline $12 \mathrm{R}-1,43-47$ & 8 & 40.93 & 9.34 & 0.14 & 49.91 & 0.41 & 0.03 & 100.76 & 90.50 & \pm 0.08 \\
\hline $12 \mathrm{R}-1,78-83$ & 8 & 40.47 & 9.37 & 0.14 & 49.60 & 0.40 & 0.05 & 100.03 & 90.42 & \pm 0.16 \\
\hline $12 R-2,60-64$ & 8 & 40.72 & 9.27 & 0.15 & 49.66 & 0.42 & 0.03 & 100.25 & 90.52 & \pm 0.18 \\
\hline $12 R-5,97-100$ & 7 & 41.01 & 9.30 & 0.14 & 49.74 & 0.41 & 0.04 & 100.64 & 90.50 & \pm 0.04 \\
\hline $12 \mathrm{R}-6,8-12$ & 8 & 40.96 & 9.36 & 0.14 & 49.69 & 0.41 & 0.03 & 100.59 & 90.50 & \pm 0.19 \\
\hline $13 R-2,59-64$ & 7 & 40.62 & 9.27 & 0.15 & 49.95 & 0.39 & 0.03 & 100.41 & 90.54 & \pm 0.13 \\
\hline
\end{tabular}

Notes: $\mathrm{n}=$ the number of analyses per sample; $\mathrm{s.d}$. $=$ standard deviation. Fo is forsterite, the molar ratio $100 \mathrm{Mg} /(\mathrm{Mg}+\mathrm{Fe})$.

Table 2. Clinopyroxene compositions in Site 920 peridotites.

\begin{tabular}{|c|c|c|c|c|c|c|c|c|c|c|c|c|c|c|}
\hline $\begin{array}{l}\text { Core, section, } \\
\text { interval }(\mathrm{cm})\end{array}$ & $\mathrm{n}$ & $\mathrm{SiO}_{2}$ & $\mathrm{TiO}_{2}$ & $\mathrm{Al}_{2} \mathrm{O}_{3}$ & $\mathrm{Cr}_{2} \mathrm{O}_{3}$ & $\mathrm{FeO}^{t}$ & $\mathrm{MnO}$ & $\mathrm{MgO}$ & $\mathrm{NiO}$ & $\mathrm{CaO}$ & $\mathrm{Na}_{2} \mathrm{O}$ & Total & Mg\# & 1 s.d. \\
\hline \multicolumn{15}{|l|}{ 153-920D- } \\
\hline $8 \mathrm{R}-2,94-100$ & 6 & 51.27 & 0.10 & 5.21 & 1.26 & 3.01 & 0.09 & 17.79 & 0.05 & 21.03 & 0.07 & 99.88 & 91.33 & \pm 0.39 \\
\hline $8 R-3,13-18$ & 6 & 50.89 & 0.10 & 4.90 & 1.20 & 2.62 & 0.09 & 17.58 & 0.06 & 21.43 & 0.08 & 98.95 & 92.28 & \pm 0.34 \\
\hline $11 \mathrm{R}-4,9-16$ & 7 & 51.39 & 0.08 & 5.05 & 1.20 & 2.71 & 0.09 & 17.78 & 0.06 & 21.23 & 0.06 & 99.65 & 92.13 & \pm 0.32 \\
\hline $12 R-4,6-12$ & 8 & 51.88 & 0.10 & 4.36 & 1.04 & 2.11 & 0.09 & 17.20 & 0.05 & 23.10 & 0.08 & 100.01 & 93.57 & \pm 0.65 \\
\hline $14 \mathrm{R}-4,67-71$ & 8 & 51.61 & 0.08 & 5.00 & 1.19 & 2.62 & 0.10 & 17.94 & 0.06 & 20.94 & 0.07 & 99.61 & 92.34 & \pm 0.71 \\
\hline $14 \mathrm{R}-4,67-71 \mathrm{r}$ & 6 & 51.41 & 0.09 & 5.18 & 1.25 & 3.25 & 0.10 & 18.30 & 0.06 & 20.41 & 0.07 & 100.12 & 90.94 & \pm 0.30 \\
\hline $15 \mathrm{R}-3,21-28$ & 6 & 51.57 & 0.12 & 5.01 & 1.27 & 3.11 & 0.10 & 18.07 & 0.05 & 20.58 & 0.10 & 99.98 & 91.19 & \pm 0.35 \\
\hline $15 \mathrm{R}-4,9-16$ & 7 & 50.96 & 0.11 & 5.04 & 1.23 & 2.87 & 0.10 & 17.60 & 0.05 & 21.42 & 0.08 & 99.46 & 91.62 & \pm 0.29 \\
\hline $15 \mathrm{R}-4,102-108 \mathrm{a}$ & 6 & 51.29 & 0.10 & 5.26 & 1.26 & 3.06 & 0.09 & 17.58 & 0.05 & 21.34 & 0.08 & 100.11 & 91.12 & \pm 0.41 \\
\hline $15 \mathrm{R}-4,102-108 \mathrm{~b}$ & 5 & 51.37 & 0.10 & 5.05 & 1.24 & 2.97 & 0.09 & 17.76 & 0.06 & 21.18 & 0.08 & 99.90 & 91.44 & \pm 0.231 \\
\hline $15 R-6,59-64$ & 8 & 51.62 & 0.10 & 4.91 & 1.17 & 2.84 & 0.09 & 17.75 & 0.06 & 20.84 & 0.07 & 99.45 & 91.78 & \pm 0.58 \\
\hline $16 \mathrm{R}-1,125-131$ & 7 & 51.10 & 0.10 & 5.04 & 1.16 & 2.98 & 0.09 & 17.56 & 0.05 & 21.28 & 0.07 & 99.43 & 91.25 & \pm 0.38 \\
\hline $16 \mathrm{R}-1,125-131$ & 8 & 50.97 & 0.08 & 4.97 & 1.15 & 2.85 & 0.10 & 17.88 & 0.06 & 21.30 & 0.07 & 99.43 & 91.81 & \pm 0.31 \\
\hline $16 \mathrm{R}-3,92-98$ & 8 & 51.32 & 0.09 & 4.89 & 1.18 & 2.89 & 0.09 & 17.58 & 0.06 & 21.54 & 0.08 & 99.72 & 91.46 & \pm 0.38 \\
\hline $16 \mathrm{R}-4,14-20$ & 5 & 51.00 & 0.14 & 5.27 & 1.30 & 2.81 & 0.08 & 17.27 & 0.06 & 21.56 & 0.08 & 99.57 & 91.64 & \pm 0.38 \\
\hline $17 R-4,47-56$ & 8 & 51.32 & 0.09 & 5.05 & 1.22 & 2.68 & 0.09 & 17.82 & 0.06 & 21.78 & 0.07 & 100.18 & 92.24 & \pm 0.34 \\
\hline $22 \mathrm{R}-2,77-83$ & 9 & 51.44 & 0.10 & 4.84 & 1.18 & 2.45 & 0.09 & 17.53 & 0.06 & 21.65 & 0.11 & 99.45 & 92.74 & \pm 0.69 \\
\hline $22 \mathrm{R}-3,48-52$ & 6 & 51.40 & 0.11 & 5.06 & 1.21 & 2.88 & 0.10 & 17.58 & 0.06 & 21.08 & 0.07 & 99.55 & 91.61 & \pm 0.61 \\
\hline $22 \mathrm{R}-7,7-12$ & 6 & 51.66 & 0.09 & 5.40 & 1.28 & 3.28 & 0.11 & 18.41 & 0.06 & 19.88 & 0.06 & 100.23 & 90.97 & \pm 0.59 \\
\hline \multicolumn{15}{|l|}{ 153-920B- } \\
\hline 7R-1, 94-97 & 8 & 50.83 & 0.11 & 4.65 & 1.15 & 2.65 & 0.09 & 17.95 & 0.06 & 21.57 & 0.10 & 99.16 & 92.35 & \pm 0.32 \\
\hline $8 \mathrm{R}-1,45-51$ & 9 & 51.71 & 0.11 & 5.11 & 1.28 & 2.67 & 0.10 & 17.93 & 0.06 & 20.78 & 0.08 & 99.83 & 92.29 & \pm 0.53 \\
\hline $12 \mathrm{R}-1,43-47$ & 6 & 51.39 & 0.09 & 4.97 & 1.22 & 2.55 & 0.09 & 16.88 & 0.05 & 22.66 & 0.06 & 99.96 & 92.20 & \pm 0.38 \\
\hline $12 \mathrm{R}-1,78-83$ & 9 & 51.72 & 0.09 & 4.96 & 1.19 & 2.73 & 0.10 & 17.62 & 0.06 & 21.84 & 0.06 & 100.37 & 92.00 & \pm 0.66 \\
\hline $12 \mathrm{R}-2,60-64$ & 5 & 52.16 & 0.08 & 4.29 & 0.98 & 2.61 & 0.09 & 17.61 & 0.05 & 22.33 & 0.06 & 100.26 & 92.33 & \pm 0.76 \\
\hline $12 \mathrm{R}-6,8-12$ & 5 & 51.59 & 0.1 & 4.94 & 1.17 & 2.7 & 0.1 & 17.4 & 0.06 & 21.7 & 0.1 & 99.86 & 92.02 & \pm 0.46 \\
\hline $13 R-2,59-64$ & 5 & 51.56 & 0.09 & 5.17 & 1.25 & 2.76 & 0.09 & 17.38 & 0.05 & 21.75 & 0.07 & 100.17 & 91.82 & \pm 0.31 \\
\hline
\end{tabular}

Notes: $\mathrm{FeO}$ ' $=$ total iron as $\mathrm{FeO} . \mathrm{Mg} \#$ is the molar ratio $100 \mathrm{Mg} /(\mathrm{Mg}+\mathrm{Fe})$ with all iron as $\mathrm{FeO}$. In some cases, more than one thin section was prepared from a sample. The suffixes "r,"

"a," and "b" denote subsamples. Other symbols and abbreviations are as in Table 1.

num oxide contents in clinopyroxene vary from 4.4 to $5.4 \mathrm{wt} \%$. In Figure $1, \mathrm{Mg} \#$ vs. $\mathrm{Al}_{2} \mathrm{O}_{3}$ in clinopyroxene is shown for the Leg 153 peridotites and for other abyssal peridotites. The Leg 153 data define a trend in which $\mathrm{Al}_{2} \mathrm{O}_{3}$ decreases with increasing $\mathrm{Mg} \#$, but less steeply than the trend exhibited by abyssal peridotites overall. $\mathrm{Al}_{2} \mathrm{O}_{3}$ levels in MARK peridotites lie approximately midway between the least and most depleted abyssal peridotites. Chromium oxide varies from 1.0 to $1.3 \mathrm{wt} \% . \mathrm{Cr}_{2} \mathrm{O}_{3}$ decreases moderately as $\mathrm{Mg} \#$ in clinopyroxene increases (Fig. 2). Mean titanium oxide varies from 0.08 to $0.14 \mathrm{wt} \%$ (Fig. 3), and mean sodium oxide varies from 0.06 to $0.11 \mathrm{wt} \%$ (Fig.
4). Sodium and titanium oxides in Leg 153 peridotites are near the most depleted compositions of abyssal peridotites overall.

Mean $\mathrm{Mg \#}$ in orthopyroxene ranges from 90.5 to 91.7 . Figure 5 shows $\mathrm{Mg} \#$ vs. $\mathrm{Al}_{2} \mathrm{O}_{3}$ in orthopyroxene. Mean $\mathrm{Al}_{2} \mathrm{O}_{3}$ in orthopyroxene varies from 3.7 to $4.6 \mathrm{wt} \%$. Chromium oxide in orthopyroxene varies from 0.76 to $0.97 \mathrm{wt} \%$. CaO contents in orthopyroxene range from 1.8 to 2.4 wt\%. Orthopyroxene data are presented in Table 3. The most interesting feature of mineral compositions in Leg 153 peridotites is the apparent difference between the degree of depletion suggested by $\mathrm{Al}_{2} \mathrm{O}_{3}$ in pyroxenes and that suggested by $\mathrm{Na}_{2} \mathrm{O}$ and 


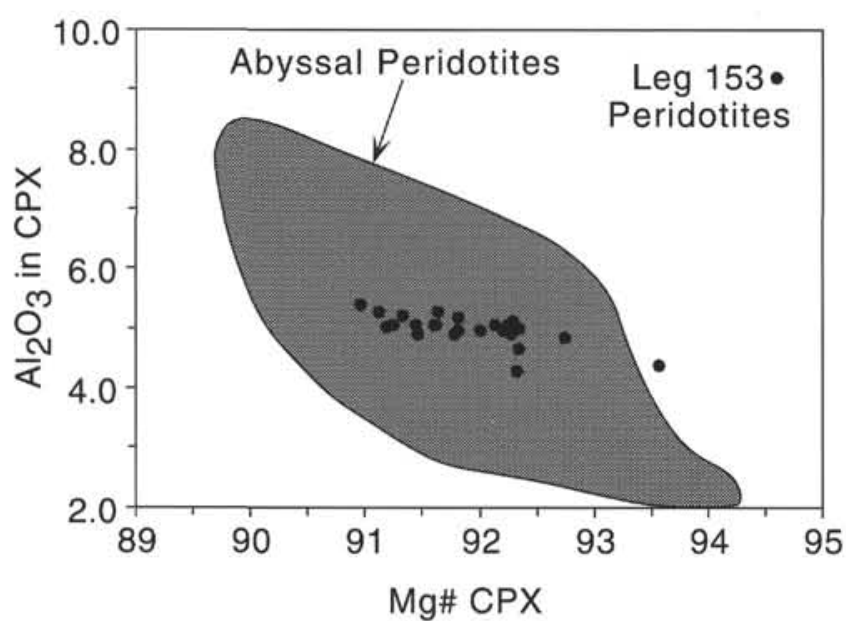

Figure 1. $\mathrm{Mg} \#$ of clinopyroxene (CPX) vs. $\mathrm{Al}_{2} \mathrm{O}_{3}(\mathrm{wt} \%)$ in clinopyroxene. Data for abyssal peridotites from Johnson et al. (1990), Johnson and Dick (1992), Bonatti et al. (1992), Michael and Bonatti (1985), Shibata and Thompson (1986), Arai and Fujii (1979), Hamlyn and Bonatti (1980), and Sinton (1979).

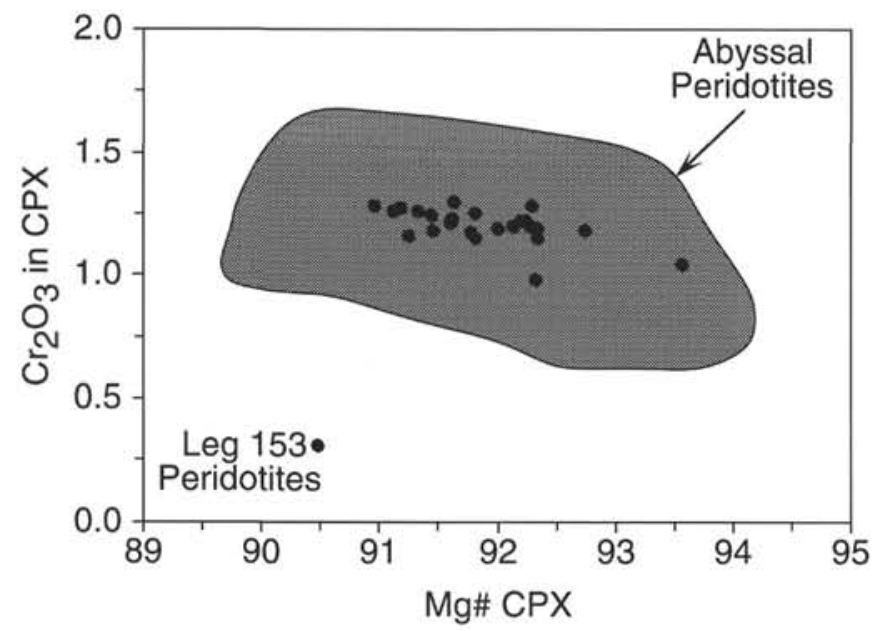

Figure 2. $\mathrm{Mg} \#$ in clinopyroxene vs. $\mathrm{Cr}_{2} \mathrm{O}_{3}$ (wt $\%$ ) in clinopyroxene. Data sources and abbreviations as in Figure 1.

$\mathrm{TiO}_{2}$. Aluminum in pyroxenes has been viewed as a function of the degree of melting of abyssal peridotites (Michael and Bonatti, 1985). The alumina contents in orthopyroxene and clinopyroxene suggest that the degree of melting in the MARK area proceeded to intermediate levels of depletion, but the $\mathrm{Na}_{2} \mathrm{O}$ and $\mathrm{TiO}_{2}$ contents are quite low, suggesting more extreme degrees of melting.

$\mathrm{Cr}$ spinel in MARK peridotites have Cr\# values of 27 to 31 with $\mathrm{Mg} \#$ values of 72 to $70 . \mathrm{TiO}_{2}$ in $\mathrm{Cr}$ spinel varies from 0.03 to 0.08 wt\% (data displayed in Table 4). Ferric iron in these $\mathrm{Cr}$ spinels is low, with the ratio $100 \cdot \mathrm{Fe}^{3+} /\left(\mathrm{Cr}+\mathrm{Al}+\mathrm{Fe}^{3+}\right)$ varying from 0.8 to 1.4 . In Figure 6, the $\mathrm{Cr} \#$ of spinel is plotted vs. the Mg\# of spinel in MARK peridotites and other abyssal peridotites. Ocean Drilling Program (ODP) Leg 109, at Site 670, drilled peridotites exposed approximately $15 \mathrm{~km}$ south of Site 920 , and these peridotites also had low $\mathrm{Cr} \#$ (19-30, Juteau et al., 1990; Komor et al., 1990). The Cr\# of spinel in abyssal peridotites is interpreted to be a function of the degree of melting (Dick and Bullen, 1984), with the low-Cr\# spinels representing less-depleted peridotite and high-Cr\# spinels representing moredepleted peridotite (higher extents of melting). The MARK samples again show evidence for less extensive melting, with $\mathrm{Cr} \#$ closer to those in relatively fertile mantle. This reinforces the apparent contra-

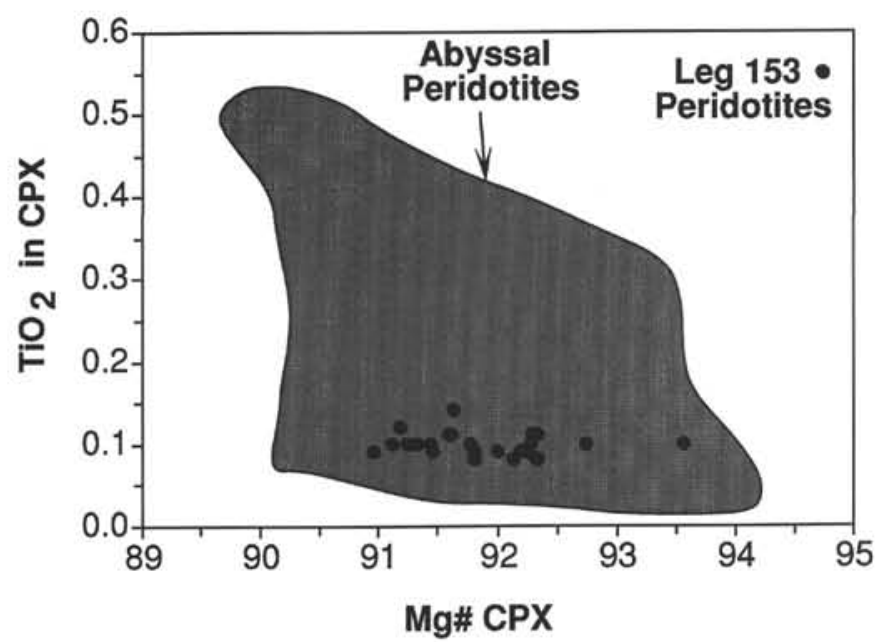

Figure 3. $\mathrm{Mg} \#$ vs. $\mathrm{TiO}_{2}(\mathrm{wt} \%)$ in clinopyroxene. Data sources and abbrevia-

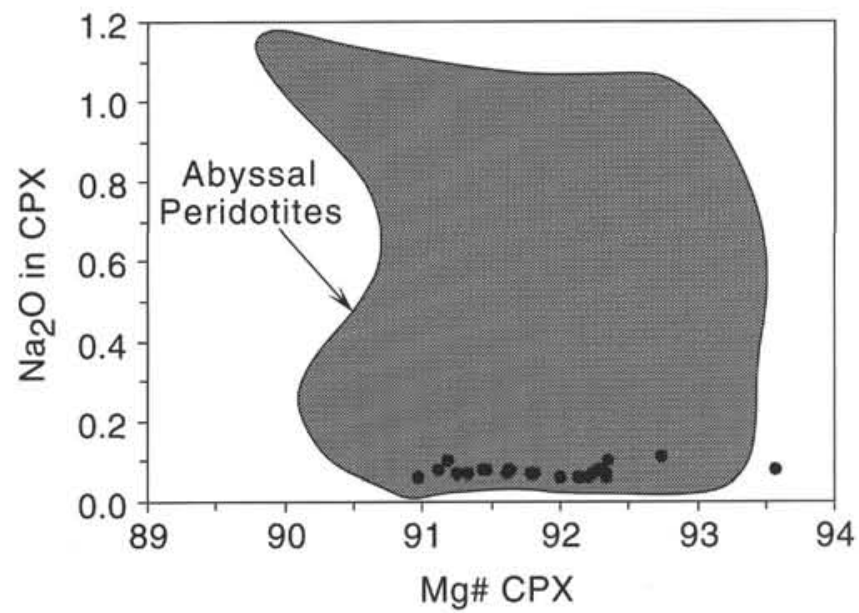

Figure 4. $\mathrm{Mg \#}$ vs. $\mathrm{Na}_{2} \mathrm{O}$ (wt\%) in clinopyroxene. Data sources and abbreviations as in Figure 1.

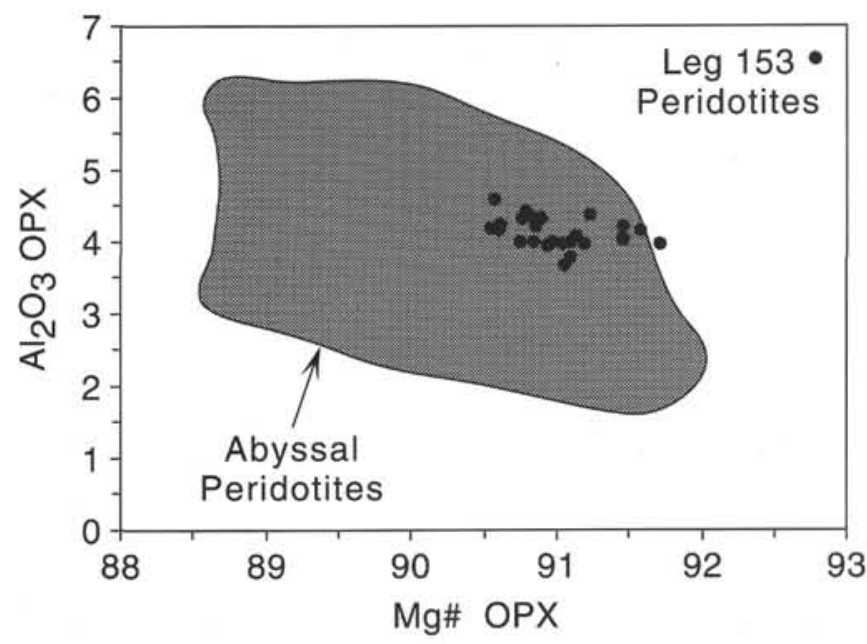

Figure 5. $\mathrm{Mg \#}$ vs. $\mathrm{Al}_{2} \mathrm{O}_{3}(\mathrm{wt} \%)$ in orthopyroxene. Data sources and abbreviations as in Figure 1. 
Table 3. Orthopyroxene compositions in Site 920 peridotites.

\begin{tabular}{|c|c|c|c|c|c|c|c|c|c|c|c|c|c|c|}
\hline $\begin{array}{l}\text { Core, section, } \\
\text { interval }(\mathrm{cm})\end{array}$ & $\mathrm{n}$ & $\mathrm{SiO}_{2}$ & $\mathrm{TiO}_{2}$ & $\mathrm{Al}_{2} \mathrm{O}_{3}$ & $\mathrm{Cr}_{2} \mathrm{O}_{3}$ & $\mathrm{FeO}^{t}$ & $\mathrm{MnO}$ & $\mathrm{MgO}$ & $\mathrm{NiO}$ & $\mathrm{CaO}$ & $\mathrm{Na}_{2} \mathrm{O}$ & Total & Mg\# & 1 s.d. \\
\hline \multicolumn{15}{|l|}{ 153-920D- } \\
\hline $8 \mathrm{R}-2,94-100$ & 6 & 54.63 & 0.05 & 4.20 & 0.90 & 5.96 & 0.13 & 32.00 & 0.10 & 2.01 & 0.01 & 99.99 & 90.54 & \pm 0.13 \\
\hline $8 \mathrm{R}-3,13-18$ & 6 & 54.52 & 0.04 & 4.32 & 0.95 & 5.65 & 0.13 & 31.65 & 0.11 & 2.14 & 0.01 & 99.52 & 90.90 & \pm 0.21 \\
\hline $11 R-4,9-16$ & 6 & 54.48 & 0.04 & 3.97 & 0.80 & 5.68 & 0.14 & 32.37 & 0.11 & 2.07 & 0.01 & 99.67 & 91.04 & \pm 0.24 \\
\hline $12 R-4,6-12$ & 7 & 54.80 & 0.04 & 4.16 & 0.86 & 5.33 & 0.14 & 32.46 & 0.11 & 1.83 & 0.01 & 99.74 & 91.57 & \pm 0.54 \\
\hline $14 R-4,67-71$ & 7 & 54.74 & 0.03 & 4.03 & 0.85 & 5.37 & 0.13 & 32.25 & 0.10 & 2.04 & 0.01 & 99.55 & 91.46 & \pm 0.35 \\
\hline $14 \mathrm{R}-4,67-71 \mathrm{r}$ & 5 & 54.82 & 0.04 & 3.88 & 0.78 & 5.91 & 0.13 & 32.27 & 0.11 & 2.09 & 0.02 & 100.05 & 90.69 & \pm 0.06 \\
\hline $15 \mathrm{R}-3,21-28$ & 6 & 55.07 & 0.05 & 3.68 & 0.76 & 5.65 & 0.14 & 32.28 & 0.11 & 1.97 & 0.02 & 99.73 & 91.06 & \pm 0.13 \\
\hline $15 R-4,9-16$ & 6 & 54.90 & 0.04 & 4.01 & 0.84 & 5.75 & 0.13 & 31.96 & 0.11 & 2.24 & 0.01 & 99.99 & 90.84 & \pm 0.32 \\
\hline $15 R-4,102-108 a$ & 5 & 54.75 & 0.04 & 4.17 & 0.89 & 5.93 & 0.14 & 32.06 & 0.10 & 2.17 & 0.01 & 100.26 & 90.60 & \pm 0.10 \\
\hline $15 \mathrm{R}-4,102-108 \mathrm{~b}$ & 5 & 55.05 & 0.04 & 4.01 & 0.82 & 5.90 & 0.13 & 32.46 & 0.10 & 1.77 & 0.01 & 100.29 & 90.75 & \pm 0.15 \\
\hline $15 R-6,59-64$ & 7 & 55.02 & 0.04 & 3.94 & 0.83 & 5.68 & 0.14 & 31.96 & 0.10 & 1.87 & 0.01 & 99.59 & 90.93 & \pm 0.16 \\
\hline $16 \mathrm{R}-1,125-131$ & 6 & 54.38 & 0.04 & 4.23 & 0.88 & 5.91 & 0.14 & 31.97 & 0.12 & 2.14 & 0.01 & 99.82 & 90.61 & \pm 0.06 \\
\hline $16 \mathrm{R}-1,125-131$ & 6 & 54.51 & 0.04 & 4.08 & 0.84 & 5.63 & 0.14 & 32.46 & 0.11 & 1.98 & 0.01 & 99.80 & 91.13 & \pm 0.31 \\
\hline $16 \mathrm{R}-3,92-98$ & 6 & 54.63 & 0.04 & 4.21 & 0.91 & 5.35 & 0.14 & 32.13 & 0.11 & 2.16 & 0.01 & 99.69 & 91.46 & \pm 0.53 \\
\hline $16 \mathrm{R}-4,14-20$ & 5 & 54.37 & 0.06 & 4.44 & 0.97 & 5.72 & 0.13 & 31.58 & 0.11 & 2.35 & 0.01 & 99.74 & 90.78 & \pm 0.10 \\
\hline $17 \mathrm{R}-4,47-56$ & 7 & 54.09 & 0.05 & 4.35 & 0.93 & 5.79 & 0.14 & 32.18 & 0.10 & 2.18 & 0.01 & 99.82 & 90.83 & \pm 0.18 \\
\hline $22 \mathrm{R}-2,77-83$ & 7 & 54.52 & 0.04 & 4.05 & 0.84 & 5.39 & 0.13 & 32.33 & 0.10 & 1.95 & 0.01 & 99.36 & 91.45 & \pm 0.39 \\
\hline $22 \mathrm{R}-3,48-52$ & 6 & 54.92 & 0.04 & 3.98 & 0.80 & 5.52 & 0.15 & 32.07 & 0.10 & 1.93 & 0.01 & 99.52 & 91.19 & \pm 0.28 \\
\hline $22 \mathrm{R}-7,7-12$ & 6 & 55.32 & 0.05 & 4.00 & 0.81 & 5.59 & 0.14 & 32.05 & 0.10 & 2.04 & 0.01 & 100.11 & 91.09 & \pm 0.29 \\
\hline \multicolumn{15}{|l|}{ 153-920B- } \\
\hline $7 \mathrm{R}-1,94-97$ & 7 & 54.62 & 0.05 & 3.79 & 0.79 & 5.74 & 0.15 & 32.97 & 0.10 & 1.49 & 0.01 & 99.71 & 91.10 & \pm 0.34 \\
\hline $8 \mathrm{R}-1,45-51$ & 5 & 55.11 & 0.05 & 3.98 & 0.87 & 5.21 & 0.13 & 32.34 & 0.11 & 1.92 & 0.01 & 99.73 & 91.71 & \pm 0.69 \\
\hline $12 \mathrm{R}-1,43-47$ & 5 & 54.51 & 0.04 & 4.38 & 0.93 & 5.47 & 0.13 & 31.90 & 0.10 & 2.06 & 0.01 & 99.53 & 91.23 & \pm 0.21 \\
\hline $12 \mathrm{R}-1,78-83$ & 7 & 55.30 & 0.04 & 4.00 & 0.81 & 5.76 & 0.15 & 32.57 & 0.10 & 2.03 & 0.01 & 100.77 & 90.98 & \pm 0.22 \\
\hline $12 \mathrm{R}-2,60-64$ & 4 & 54.89 & 0.05 & 4.59 & 0.96 & 5.92 & 0.13 & 31.88 & 0.11 & 2.03 & 0.01 & 100.57 & 90.57 & \pm 0.08 \\
\hline $12 R-6,8-12$ & 5 & 54.69 & 0.05 & 4.22 & 0.88 & 5.7 & 0.13 & 31.76 & 0.09 & 2.26 & 0.02 & 99.80 & 90.85 & \pm 0.04 \\
\hline $13 R-2,59-64$ & 5 & 54.66 & 0.05 & 4.32 & 0.91 & 5.78 & 0.13 & 31.85 & 0.10 & 2.19 & 0.01 & 100.00 & 90.76 & \pm 0.18 \\
\hline
\end{tabular}

Note: Symbols and abbreviations as in Tables 1 and 2.

Table 4. Chrome spinel compositions in Site 920 peridotites.

\begin{tabular}{|c|c|c|c|c|c|c|c|c|c|c|c|c|c|c|}
\hline \multirow{2}{*}{$\begin{array}{l}\text { Core, section, } \\
\text { interval }(\mathrm{cm})\end{array}$} & \multirow[b]{2}{*}{$\mathrm{n}$} & \multirow[b]{2}{*}{$\mathrm{SiO}_{2}$} & \multirow[b]{2}{*}{$\mathrm{TiO}_{2}$} & \multirow[b]{2}{*}{$\mathrm{Cr}_{2} \mathrm{O}_{3}$} & \multirow[b]{2}{*}{$\mathrm{Al}_{2} \mathrm{O}_{3}$} & \multirow[b]{2}{*}{$\mathrm{FeO}^{t}$} & \multirow[b]{2}{*}{$\mathrm{MnO}$} & \multirow[b]{2}{*}{$\mathrm{MgO}$} & \multirow[b]{2}{*}{$\mathrm{NiO}$} & \multicolumn{2}{|c|}{ Recalculated } & \multirow[b]{2}{*}{ Total } & \multirow[b]{2}{*}{$\mathrm{Cr} \#$} & \multirow[b]{2}{*}{ Mg\# } \\
\hline & & & & & & & & & & $\mathrm{FeO}$ & $\mathrm{Fe}_{2} \mathrm{O}_{3}$ & & & \\
\hline \multicolumn{15}{|l|}{ 153-920D- } \\
\hline $11 R-4,9-16$ & 7 & 0.01 & 0.05 & 25.72 & 43.08 & 13.26 & 0.08 & 17.22 & 0.23 & 12.38 & 0.97 & 99.74 & 28.60 & 71.26 \\
\hline $12 \mathrm{R}-4,6-12$ & 6 & 0.01 & 0.06 & 25.91 & 43.26 & 12.68 & 0.07 & 17.48 & 0.25 & 11.97 & 0.79 & 99.80 & 28.66 & 72.24 \\
\hline $14 \mathrm{R}-3,99-106$ & 6 & 0.01 & 0.05 & 25.78 & 42.65 & 13.78 & 0.09 & 17.11 & 0.25 & 12.59 & 1.31 & 99.84 & 28.85 & 70.79 \\
\hline $14 R-4,67-71$ & 5 & 0.00 & 0.05 & 25.91 & 42.86 & 13.65 & 0.07 & 17.17 & 0.25 & 12.59 & 1.16 & 100.06 & 28.86 & 70.85 \\
\hline $14 \mathrm{R}-4,134-138$ & 6 & 0.02 & 0.05 & 25.64 & 42.88 & 13.46 & 0.07 & 17.14 & 0.23 & 12.45 & 1.10 & 99.58 & 28.63 & 71.04 \\
\hline $15 R-4,9-16$ & 7 & 0.01 & 0.08 & 26.17 & 40.95 & 12.89 & 0.05 & 16.98 & 0.24 & 11.77 & 1.23 & 97.48 & 30.01 & 71.99 \\
\hline $15 R-4,102-108$ & 7 & 0.00 & 0.06 & 26.57 & 42.36 & 13.36 & 0.08 & 17.24 & 0.25 & 12.33 & 1.13 & 100.02 & 29.65 & 71.37 \\
\hline $15 \mathrm{R}-6,59-64$ & 7 & 0.00 & 0.07 & 26.85 & 41.79 & 13.80 & 0.08 & 17.05 & 0.23 & 12.62 & 1.29 & 99.98 & 30.12 & 70.65 \\
\hline $16 \mathrm{R}-1,125-131$ & 6 & 0.00 & 0.05 & 25.07 & 43.29 & 12.87 & 0.07 & 17.33 & 0.24 & 12.01 & 0.95 & 99.01 & 27.98 & 72.01 \\
\hline $16 \mathrm{R}-3,92-98$ & 7 & 0.02 & 0.06 & 26.52 & 42.73 & 13.29 & 0.08 & 17.34 & 0.23 & 12.31 & 1.08 & 100.37 & 29.40 & 71.51 \\
\hline $17 \mathrm{R}-4,47-56$ & 7 & 0.01 & 0.04 & 24.62 & 43.41 & 13.15 & 0.06 & 17.00 & 0.24 & 12.39 & 0.84 & 98.61 & 27.56 & 70.97 \\
\hline $22 \mathrm{R}-3,48-52$ & 6 & 0.00 & 0.04 & 26.00 & 42.88 & 13.46 & 0.07 & 17.19 & 0.23 & 12.52 & 1.04 & 99.97 & 28.92 & 71.00 \\
\hline $22 \mathrm{R}-7,7-12$ & 4 & 0.00 & 0.03 & 25.06 & 43.60 & 14.17 & 0.07 & 17.04 & 0.21 & 13.04 & 1.24 & 100.2 & 927.83 & 69.96 \\
\hline \multicolumn{15}{|l|}{ 153-920B- } \\
\hline $7 \mathrm{R}-1,94-97$ & 8 & 0.00 & 0.08 & 27.50 & 40.96 & 13.59 & 0.07 & 16.92 & 0.24 & 12.50 & 1.20 & 99.47 & 31.05 & 70.7 \\
\hline $12 \mathrm{R}-1,78-83$ & 8 & 0.00 & 0.05 & 25.85 & 42.55 & 13.09 & 0.07 & 17.15 & 0.24 & 12.21 & 0.97 & 99.09 & 28.95 & 71.46 \\
\hline $12 \mathrm{R}-5,97-100$ & 6 & 0.01 & 0.05 & 26.38 & 42.40 & 13.25 & 0.08 & 17.32 & 0.24 & 12.20 & 1.15 & 99.83 & 29.45 & 71.66 \\
\hline $12 \mathrm{R}-6,8-12$ & 6 & 0.01 & 0.06 & 26.15 & 42.58 & 13.28 & 0.07 & 17.32 & 0.24 & 12.23 & 1.15 & 99.81 & 29.17 & 71.62 \\
\hline $13 R-2,59-64$ & 6 & 0.02 & 0.06 & 25.86 & 42.67 & 13.31 & 0.07 & 17.22 & 0.24 & 12.28 & 1.14 & 99.56 & 28.91 & 71.43 \\
\hline
\end{tabular}

Notes: $\mathrm{n}=$ the number of analyses per sample. $\mathrm{Mg} \#$ is the molar ratio $100 \mathrm{Mg} /\left(\mathrm{Mg}+\mathrm{Fe}^{2+}\right), \mathrm{Cr} \#$ is the molar ratio $100 \mathrm{Cr} /(\mathrm{Cr}+\mathrm{Al}) . \mathrm{FeO}{ }^{t}=t$ total iron as $\mathrm{FeO}$, Iron is recalculated on the basis of stoichiometry and charge balance.

diction mentioned above, with $\mathrm{Cr} \#$ in spinel and $\mathrm{Al}$ in pyroxenes suggesting lower degrees of melting, and minor elements in clinopyroxene, such as $\mathrm{TiO}_{2}$ and $\mathrm{Na}_{2} \mathrm{O}$, suggesting more extensive melting.

\section{TRACE-ELEMENT ABUNDANCES IN DIOPSIDE}

Rare-earth elements, minor elements, and other trace elements have been determined in clinopyroxene in Site 920 peridotites using the ion probe. These data are displayed in Table 5. Figure 7A shows REE patterns for clinopyroxene in Hole 920B samples, calculated melts in equilibrium with clinopyroxene and basalts erupted near the Kane Fracture Zone (data for basalts from Bryan et al., 1981). Figure 7B shows similar data for Hole 920D. It is clear that the residual mantle south of the Kane Fracture Zone would not be in equilibrium with erupted basalts from this area. Fractional melting of the mantle led to extreme depletion, producing late-stage melts that were strongly depleted in incompatible trace elements. Rare-earth element abundances in MARK peridotite diopside are compared to those in peridotites from the southern ocean basins in Figure 8 (Vulcan and Bouvet Fracture Zone data are from Johnson et al., 1990). Vulcan Fracture Zone samples are the least depleted abyssal peridotites in terms of rareearth elements, and the Bouvet Fracture Zone samples are the most depleted among samples studied by Johnson et al. (1990) and Johnson and Dick (1992). The MARK data have similar levels of depletion as the Bouvet data in light REEs (LREEs) and heavy REEs, but are not as low in middle REEs. The extreme levels of depletion in the Bouvet samples were attributed to extensive melting associated with plume activity. The data in this study, and that in Hess Deep samples (Dick and Natland, 1996) show that extreme depletion of the 
mantle is not unique to plume-influenced locations. At Hess Deep, the peridotites are strongly depleted in both major- and trace-element indicators of degree of melting, in contrast to Leg 153 peridotites, which are strongly depleted in incompatible trace elements, but are not so strongly depleted in major elements such as $\mathrm{Al}_{2} \mathrm{O}_{3}$ in pyroxenes and $\mathrm{Cr} \#$ in spinel. The MARK peridotites are spatially associated with basalts that are among the more enriched N-MORBs (Bryan et al., 1981; Bryan et al., 1993). The spatial association of strongly depleted peridotites with relatively enriched basalts has been noted previously (Le Roex et al., 1983). The later stages of melting in the MARK area produced melts similar to the ultradepleted melt of Sobolev and Shimizu (1993).

Mean $\mathrm{Ti}$ in clinopyroxene in the MARK peridotites ranges from 420 to $598 \mathrm{ppm}$, mean $\mathrm{Zr}$ varies from 0.3 to $1.2 \mathrm{ppm}$, and mean $\mathrm{Sr}$ from 0.4 to $1.1 \mathrm{ppm}$. $\mathrm{Mg} \#$ in clinopyroxene is plotted vs. $\mathrm{Zr}$ in clinopyroxene in Figure 9, and vs. Sr in clinopyroxene in Figure 10. The extreme levels of depletion of the MARK peridotites relative to other abyssal peridotite data is clear in these figures, although the data set presently available is limited to samples from the Southwest Indian Ridge and Hess Deep, and further studies are needed to understand the relationship between major and incompatible trace elements in abyssal peridotites. Estimated late-stage melts in equilibrium with the

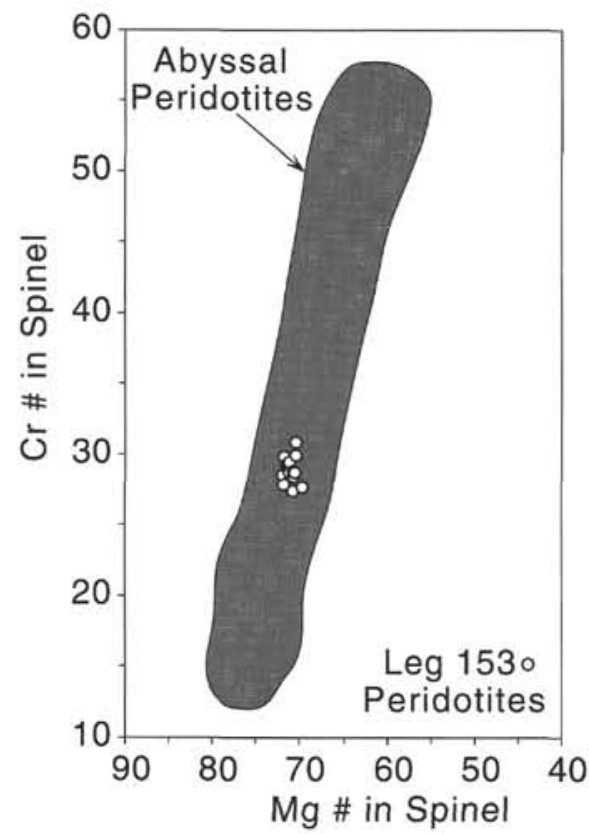

Figure 6. $\mathrm{Mg \#}$ in spinel vs. $\mathrm{Cr} \#$ in spinel. Abyssal peridotite field from Dick and Bullen (1984) and from references in caption to Figure 1.
MARK mantle (using distribution coefficients from Hart and Dunn, $1993)$ had less than $1500 \mathrm{ppm} \mathrm{Ti}\left(0.25 \mathrm{wt} \% \mathrm{TiO}_{2}\right)$, less than $10 \mathrm{ppm}$ $\mathrm{Zr}$, and less than $10 \mathrm{ppm} \mathrm{Sr}$. The level of depletion in high-fieldstrength elements (HFSEs) in these late-stage melts is similar to that in boninite magmas. It appears that the production of such strongly depleted magmas is a routine feature of magma generation at midocean ridges. Such extreme HFSE depletions in lavas or cumulate se-
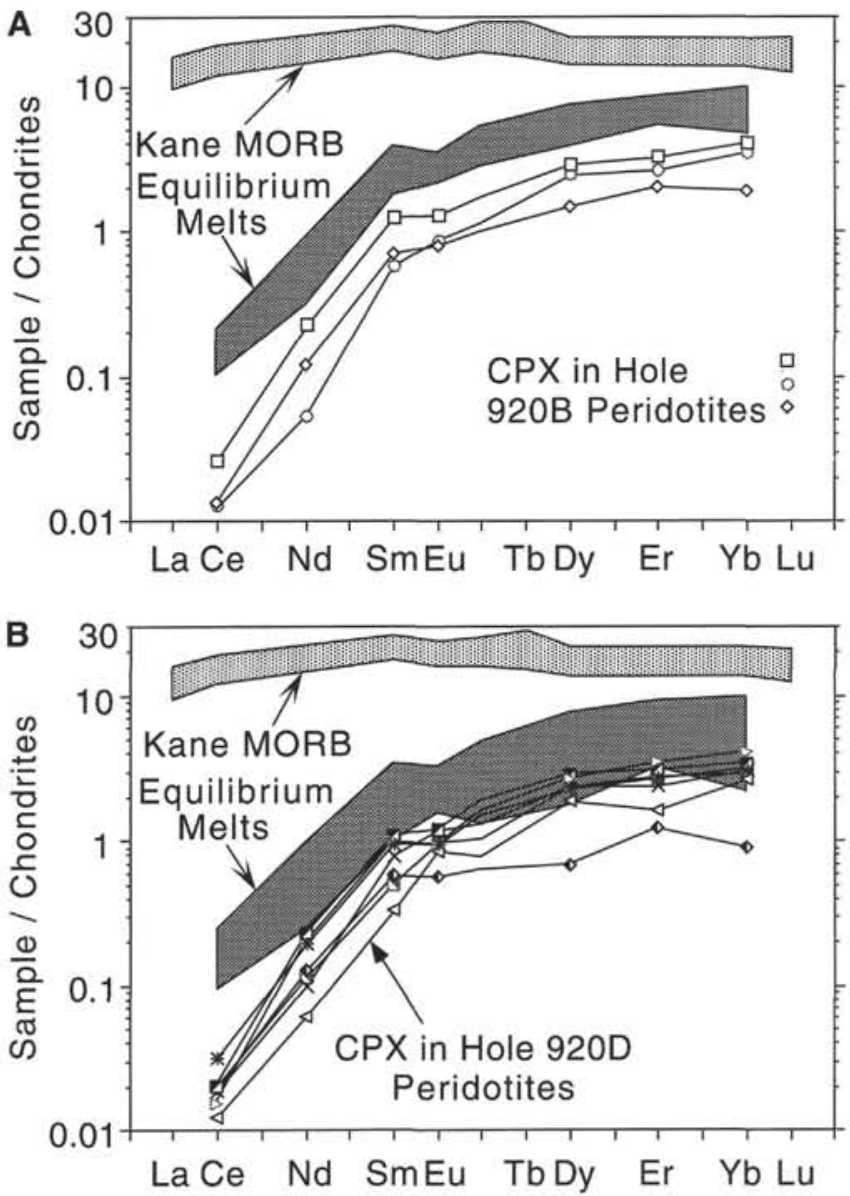

Figure 7. REE patterns of diopsides in Leg 153 peridotites. A. Hole 920B. B. Hole 920D. Also shown are melts in equilibrium with diopsides, calculated using the distribution coefficients from Grutzeck et al. (1974). Kane MORB field is from Bryan et al. (1981). REE data in this figure and those that follow were normalized to chondrite values in Anders and Ebihara (1982) multiplied by 1.27 . CPX = clinopyroxene.

Table 5. Ion probe data for diopsides in Site $\mathbf{9 2 0}$ peridotites.

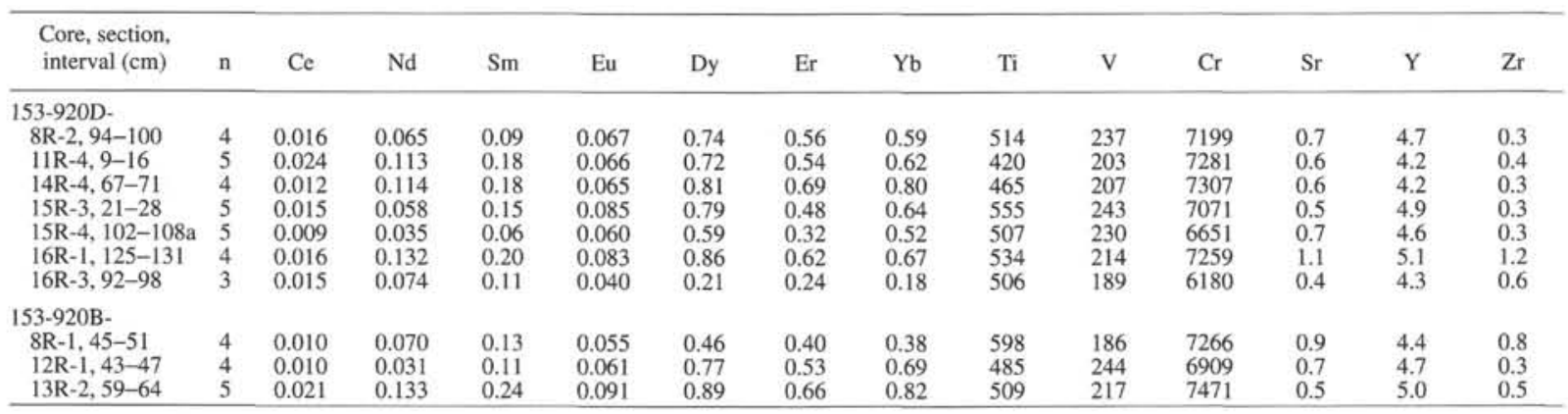

Notes: All data are in ppm. Data are average analyses, where " $\mathrm{n}$ " is the number of spots analyzed per sample. Representative analytical uncertainties at these abundance levels are $25 \%-40 \%$ for $\mathrm{Ce}, \mathrm{Eu}, \mathrm{Zr}$, and $\mathrm{Nd} ; 10 \%-20 \%$ for $\mathrm{Sm}, \mathrm{Sr}$, and $\mathrm{Er}$; and $3 \%-10 \%$ for $\mathrm{Yb}, \mathrm{Tr}, \mathrm{V}, \mathrm{Y}$, and $\mathrm{Cr}$. The suffix "a" is as in Table 2 . 


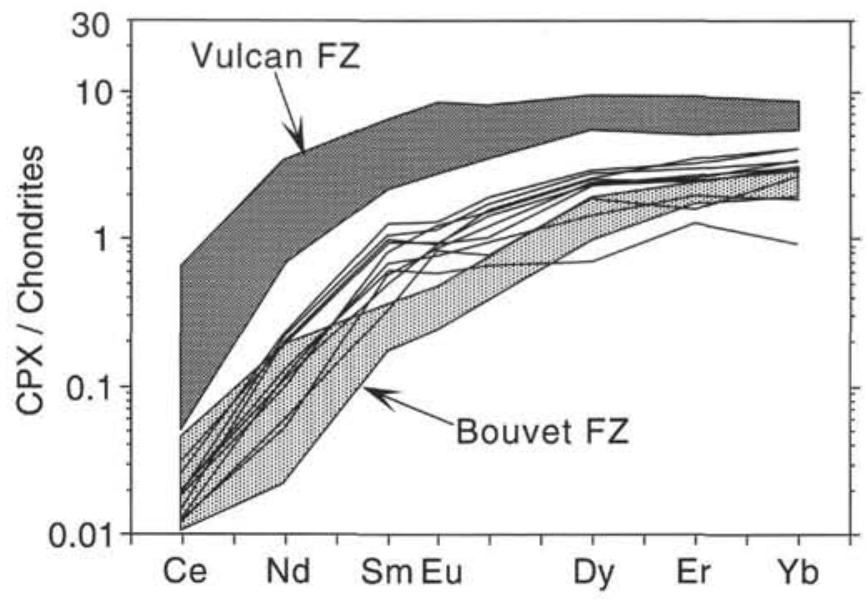

Figure 8. REE patterns of diopsides in Leg 153 peridotites and from Vulcan and Bouvet Fracture Zone (FZ) peridotites. Vulcan and Bouvet data from Johnson et al. (1990). The Vulcan and Bouvet data define the upper and lower limits of REE compositions in diopsides among currently published data. $\mathrm{CPX}=$ clinopyroxene.

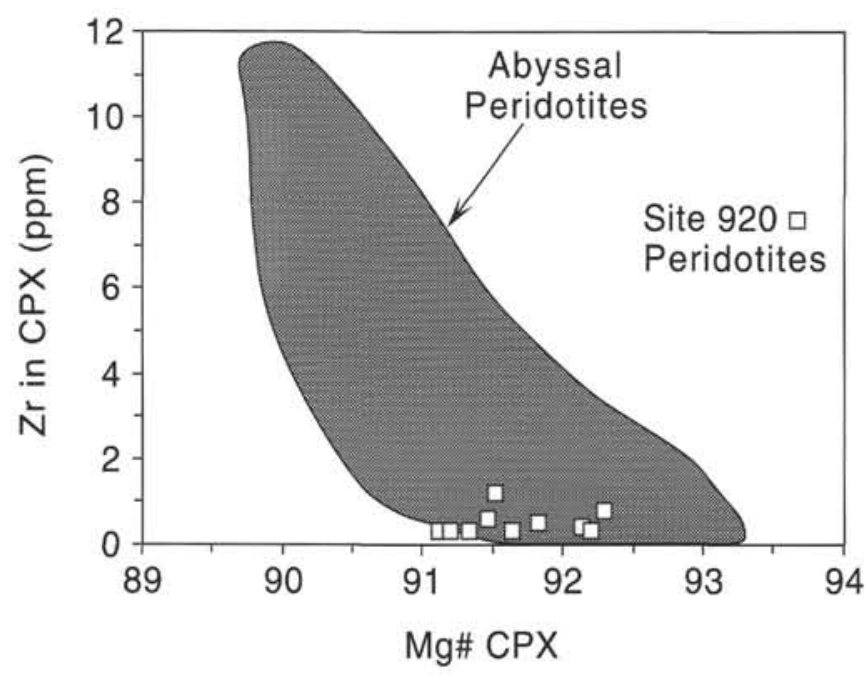

Figure 9. Mg\# vs. Zr in clinopyroxene (CPX) from Leg 153 and other abyssal peridotites. Data for other abyssal peridotites are from Johnson et al. (1990) and Johnson and Dick (1992).

quences in ophiolites are now routinely cited as evidence for an arcrelated origin for these ophiolites, but the data that have become available for abyssal peridotites and some oceanic cumulates (Ross and Elthon, 1993) make it clear that mid-ocean ridges produce latestage melts that have arc-like levels of HFSEs.

\section{DISCUSSION}

Quantitative estimates of the degree of melting for the MARK peridotites depend on assumptions of the starting mantle composition at the initial stages of melting. The rather uniform, low abundances of trace elements in these peridotites provide no constraints on the composition of the mantle prior to melting, so that any estimates of melting derived from the Leg 153 data set are wholly dependent on assumptions about the initial mantle composition. Approximately $12 \%-20 \%$ fractional melting of primitive upper mantle (PUM; Sun and McDonough, 1989) would be required to produce the extreme trace-element depletions observed in the MARK mantle (see Johnson et al. [1990] for fractional melting equations and modeling and

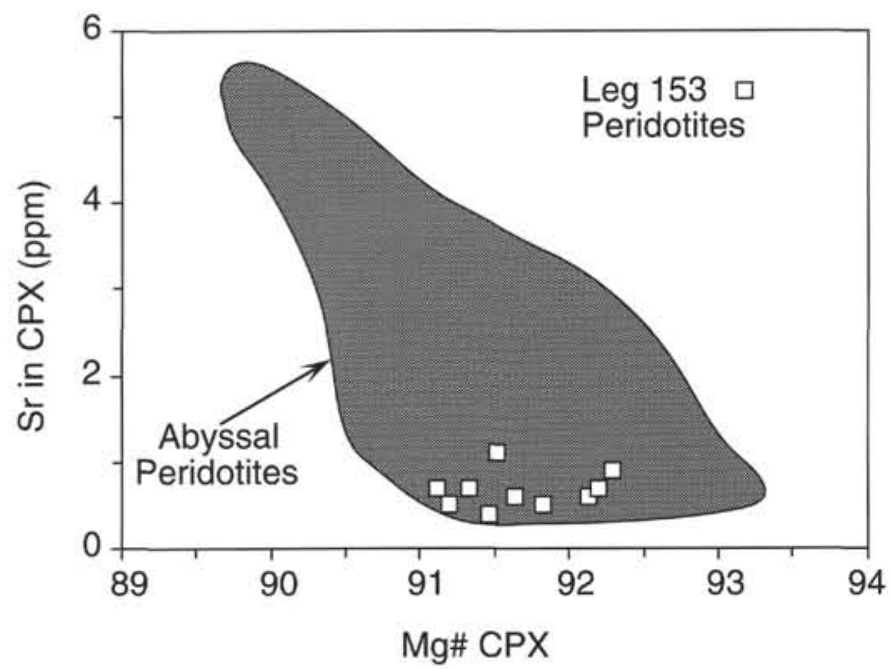

Figure 10. Mg\# vs. Sr in clinopyroxene (CPX) from Leg 153 and other abyssal peridotites. Data for other abyssal peridotites are from Johnson et al. (1990) and Johnson and Dick (1992).

Elthon [1992] for fractional melting models based on PUM). As noted above, $\mathrm{Al}$ in pyroxenes and $\mathrm{Cr} \#$ in spinels suggest less extensive melting for the MARK mantle, although we have not developed quantitative models of $\mathrm{Al}$ and $\mathrm{Cr}$ behavior during melting. A possible resolution of this apparent contradiction is suggested by the data plotted in Figure 11, where $\mathrm{Ce} / \mathrm{Yb}_{n}$ in clinopyroxene is plotted vs. $\mathrm{Cr} \#$ in coexisting spinel for various abyssal peridotites. The data define a curved path with low $\mathrm{Cr} \#$ in spinel associated with high $\mathrm{Ce} / \mathrm{Yb}_{\mathrm{n}}$ in clinopyroxene, trending toward very low $\mathrm{Ce} / \mathrm{Yb}_{\mathrm{n}}$ at high $\mathrm{Cr} \#$ in spinel. It appears from these data that the initial stages of fractional melting result in an early collapse in light to heavy rare-earth element ratios, because of early collapse in light rare-earth element abundances, and that continued melting results in progressive increase in $\mathrm{Cr} \#$ at low $\mathrm{Ce} / \mathrm{Yb}_{\mathrm{n}}$. $\mathrm{Al}$ in pyroxenes is dependent not only of degree of melting, but also pressure of melting and perhaps also subsolidus equilibration between $\mathrm{Cr}$ spinel and pyroxenes. We cannot rule out the influence of starting mantle heterogeneity on the ultimate compositions reached during melting in these samples. It is interesting to note that both the Hess Deep and MARK data show some variability in $\mathrm{Ce} / \mathrm{Yb}_{\mathrm{n}}$ and scatter toward higher $\mathrm{Ce} / \mathrm{Yb}_{\mathrm{n}}$ at essentially constant $\mathrm{Cr} \#$ in spinel (defining a trend that is normal to the curve defined by the data set a whole). This feature suggests that Hess Deep and Leg 153 peridotites have interacted with melts or have been re-impregnated with melt, causing local enrichments in LREEs and increases in $\mathrm{Ce} / \mathrm{Yb}_{\mathrm{n}}$.

In Figure $12, \mathrm{Al}_{2} \mathrm{O}_{3}$ is plotted vs. the $\mathrm{TiO}_{2}$ contents of diopsides in abyssal peridotites, from the same set of samples that was used to construct previous plots (samples for which REE and other incompatible trace-element data are available). This plot shows that these samples define two groups: one that has relatively high $\mathrm{Al}$ and $\mathrm{Ti}$, and a second that has much lower $\mathrm{Al}$ and $\mathrm{Ti}$. There is a discontinuity in $\mathrm{TiO}_{2}$ contents between these two groups at approximately $5 \mathrm{wt} \%$ $\mathrm{Al}_{2} \mathrm{O}_{3}$. Samples from the Vulcan Fracture Zone and some from the Atlantis II Fracture Zone make up the high $\mathrm{TiO}_{2}$, high $\mathrm{Al}_{2} \mathrm{O}_{3}$ group. Samples from the other localities make up the low $\mathrm{TiO}_{2}$ group. These data suggest that the low $\mathrm{TiO}_{2}$ group, (including the Site 920 samples) result from melting of a mantle source that was initially more depleted in $\mathrm{TiO}_{2}$ (and perhaps other incompatible elements) than the mantle source of the other group.

\section{CONCLUSIONS}

Extraction of basaltic melt from the MARK mantle resulted in extreme depletion of incompatible trace elements in clinopyroxene in 


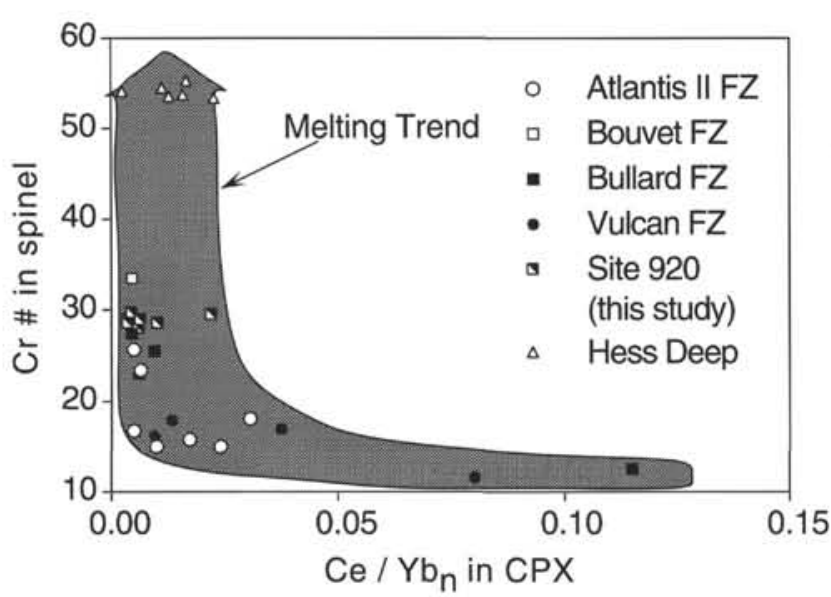

Figure 11. $(\mathrm{Ce} / \mathrm{Yb})_{\mathrm{n}}$ in clinopyroxene $(\mathrm{CPX})$ vs. $\mathrm{Cr} \#$ in spinel in abyssal peridotites. Data for Bouvet, Bullard, and Vulcan Fracture Zones (FZ) from Johnson et al. (1990), Atlantis II Fracture Zone data are from Johnson and Dick (1992), and data from Hess Deep are from Dick and Natland (1996).

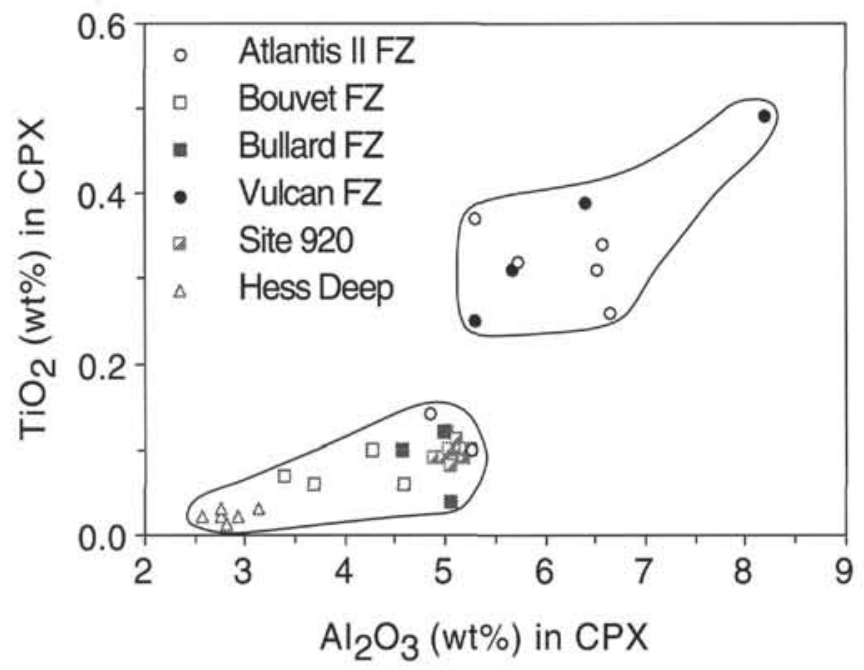

Figure $12 . \mathrm{TiO}_{2}$ (wt \%) in clinopyroxene $(\mathrm{CPX})$ vs. $\mathrm{Al}_{2} \mathrm{O}_{3}$ (wt \%) in clinopyroxene for abyssal peridotites. The data form two groups with a discontinuity at about $5 \% \mathrm{Al}_{2} \mathrm{U}_{3}$. Samples from Leg 153, Hess Deep, Bullard Fracture Zone (FZ), and Bouvet Fracture Zone form a group with relatively low $\mathrm{TiO}_{2}$, and those from the Vulcan and Atlantis II Fracture Zones form the group with relatively nigh $\mathrm{TiO}_{2}$. Data sources are in caption to Figure 11 .

these rocks. As with other suites of abyssal peridotites, fractional melting proceeded until the late-stage melts were much more depleted in incompatible trace elements than any erupted MORBs. Na, Ti, $\mathrm{Zr}, \mathrm{Sr}$, and rare-earth elements in clinopyroxene in MARK abyssal peridotites are well below levels that would be in equilibrium with erupted Kane basalts, or with melts that crystallized gabbroic rocks also drilled during Leg 153 (see Ross and Elthon, Chapter 17, this volume). Melting of the suboceanic mantle appears to result in an early severe depletion in incompatible trace-element abundances during initial stages of melting, with relatively small changes in other indices of the degree of melting such as $\mathrm{Cr} \#$ in spinel. Evidence suggesting heterogeneity in initial mantle composition for different abyssal peridotite locations is revealed by $\mathrm{Al}_{2} \mathrm{O}_{3}-\mathrm{TiO}_{2}$ systematics in peridotite diopsides.

\section{ACKNOWLEDGMENTS}

Access to the ion probe laboratory and assistance in the use of the instrument was provided by Dr. N. Shimizu. The authors thank
H.J.B. Dick and J. Natland for providing a preprint of one of their Leg 147 manuscripts. Support for this project was provided by the Joint Oceanographic Institutions. Excellent efforts by the ship's crew and drilling team on the JOIDES Resolution and by ODP technical support staff made this work possible.

\section{REFERENCES}

Anders, E., and Ebihara, M., 1982. Solar-system abundances of the elements. Geochim. Cosmochim. Acta., 46:2363-2380.

Arai, S., and Fujii, T., 1979. Petrology of ultramafic rocks from Site 395. In Melson, W.G., Rabinowitz, P.D., et al., Init. Repts. DSDP, 45: Washington (U.S. Govt. Printing Office), 587-594.

Bonatti, E., Peyve, A., Kepezhinskas, P., Kurentsova, N., Seyler, M., Skolotnev, S., and Udintsev, G., 1992. Upper mantle heterogeneity below the Mid-Atlantic Ridge, $0^{\circ}-15^{\circ}$ N. J. Geophys. Res., 97:4461-4476.

Bryan, W.B., Humphris, S.E., Thompson, G., and Casey, J.F., 1993. Comparative volcanology of small axial eruptive centers in the MARK area. $J$. Geophys. Res., 99:2973-2984.

Bryan, W.B., Thompson, G., and Ludden, J.N., 1981. Compositional variation in normal MORB from $22^{\circ}-25^{\circ} \mathrm{N}$ : Mid-Atlantic Ridge and Kane Fracture Zone. J. Geophys. Res., 86:11815-11836.

Cannat, M., Karson, J.A., Miller, D.J., et al., 1995. Proc. ODP, Init. Repts. 153: College Station, TX (Ocean Drilling Program).

Dick, H.J.B., and Bullen, T., 1984. Chromian spinel as a petrogenetic indicator in abyssal and alpine-type peridotites and spatially associated lavas. Contrib. Mineral. Petrol., 86:54-76.

Dick, H.J.B., and Natland, J.H., 1996. Late-stage melt evolution and transport in the shallow mantle beneath the East Pacific Rise. In Mével, C., Gillis, K.M., Allan, J.F., and Meyer, P.S. (Eds.), Proc. ODP, Sci. Results, 147: College Station, TX (Ocean Drilling Program), 103-134.

Elthon, D., 1992. Chemical trends in abyssal peridotites: refertilization of depleted suboceanic mantle. J. Geophys. Res., 97:9015-9025.

Grutzeck, M., Kridelbaugh, S., and Weill, D., 1974. The distribution of Sr and REE between diopside and silicate liquid. Geophys. Res. Lett., $1: 273-275$.

Hamlyn, P.R., and Bonatti, E., 1980. Petrology of mantle-derived ultramafics from the Owen fracture zone, northwest Indian Ocean: implications for the nature of the oceanic upper mantle. Earth Planet. Sci. Lett., 48:965979.

Hart, S.R., and Dunn, T., 1993. Experimental CPX/melt partitioning of 24 trace elements. Contrib. Mineral. Petrol., 113:1-8.

Johnson, K.T.M., and Dick, H.J.B., 1992. Open system melting and tempora and spatial variation of peridotite and basalt at the Atlantis II fracture zone. J. Geophys. Res., 97:9219-9241.

Johnson, K.T.M., Dick, H.J.B., and Shimizu, N., 1990. Melting in the oceanic upper mantle: an ion microprobe study of diopsides in abyssal peridotites. J. Geophys. Res., 95:2661-2678.

Juteau, T., Berger, E., and Cannat, M., 1990. Serpentinized, residual mantle peridotites from the M.A.R. median valley, ODP Hole $670 \mathrm{~A}\left(21^{\circ} 10^{\circ} \mathrm{N}\right.$, $45^{\circ} 02 \mathrm{~W}$, Leg 109): primary mineralogy and geothermometry. In Detrick, R., Honnorez, J., Bryan, W.B., Juteau, T., et al., Proc. ODP, Sci. Results, 106/109: College Station, TX (Ocean Drilling Program), 27-45.

Komor, S.C., Grove, T.L., and Hébert, R., 1990. Abyssal peridotites from ODP Hole $670 \mathrm{~A}\left(21^{\circ} 10^{\circ} \mathrm{N}, 45^{\circ} 02 \mathrm{~W}\right)$ : residues of mantle melting exposed by non-constructive axial divergence. In Detrick, R., Honnorez, J., Bryan, W.B., Juteau, T., et al., Proc. ODP, Sci. Results, 106/109: College Station, TX (Ocean Drilling Program), 85-101.

Le Roex, A.P., Dick, H.J.B., Reid, A.J., Frey, A.M., and Hart, S.R., 1983. Geochemistry, mineralogy and petrogenesis of lavas erupted along the Southwest Indian Ridge between the Bouvet Triple Junction and $11^{\circ} \mathrm{E}$, 1983. J. Petrol., 24:267-318.

Michael, P.J., and Bonatti, E., 1985. Peridotite composition from the North Atlantic: regional and tectonic variations and implications for partial melting. Earth Planet. Sci. Lett., 73:91-104.

Ross, K., and Elthon, D., 1993. Cumulates from strongly depleted mid-ocean ridge basalt. Nature, 365:826-829.

Shibata, T., and Thompson, G., 1986. Peridotites from the Mid-Atlantic Ridge at $43^{\circ} \mathrm{N}$ and their petrogenetic relation to abyssal tholeiites. Contrib. Mineral. Petrol., 93:144-159.

Shimizu, N., and Hart, S.R., 1982. Applications of the ion microprobe to geochemistry and cosmochemistry. Ann. Rev. Earth Planet. Sci., 10:483526. 
Sinton, J.M., 1979. Petrology of (Alpine-type) peridotites from Site 395, DSDP Leg 45. In Melson, W.G., Rabinowitz, P.D., et al., Init. Repts. DSDP, 45: Washington (U.S. Govt. Printing Office), 595-601.

Sobolev, A.V., and Shimizu, N., 1993. Ultra-depleted primary melt included in an olivine from the Mid-Atlantic Ridge. Nature, 363:151-154.

Sun, S.-S., and McDonough, W.F., 1989. Chemical and isotopic systematics of oceanic basalts: implications for mantle composition and processes. In
Saunders, A.D., and Norry, M.J. (Eds.), Magmatism in the Ocean Basins. Geol. Soc. Spec. Publ. London, 42:313-345.

Date of initial receipt: 1 August 1995

Date of acceptance: 23 April 1996

Ms 153SR-015 